\title{
Zgodność z Konstytucją RP poselskiego projektu ustawy o ograniczeniu prowadzenia działalności gospodarczej przez osoby pełniące funkcje publiczne ${ }^{1}$
}

\begin{abstract}
W projekcie ustawy zaproponowano wyodrębnienie spośród osób pełniących kierownicze stanowiska państwowe podgrupy osób, złożonej z Prezydenta, marszałków i wicemarszałków Sejmu i Senatu, Prezesa i wiceprezesów Rady Ministrów oraz ministrów, której dotyczyłby obowiązek ujawnienia nie tylko majątków osobistych tych osób i majątku objętego małżeńską wspólnością majątkową, ale również majątków osobistych ich małżonków. W ocenie autorki opinii takie określenie zakresu podmiotowego może budzić wątpliwości z punktu widzenia konstytucyjnej zasady równości. Zastrzeżenia dotyczą także zaproponowanej zasady upubliczniania danych adresowych, informacji o położeniu nieruchomości oraz informacji umożliwiających identyfikację ruchomości osoby składającej oświadczenie. Poważne wątpliwości konstytucyjne budzi publikowanie takich oświadczeń w Biuletynie Informacji Publicznej.
\end{abstract}

Słowa kluczowe: konstytucja, oświadczenie majątkowe, stanowisko państwowe, projekt ustawy

Conformity to the Constitution of the Republic of Poland of a Deputies' Bill on the Limitation of Conducting Business Activity by Persons Performing Public Functions: The bill proposes to separate from persons holding state positions a subgroup consisting of the President, Marshals and Deputy Marshals of the Sejm and Senate, the Prime Minister and Deputy Prime Ministers of the Council of Ministers and Ministers, who would be obliged to disclose not only their personal and marital property, but also personal property of their spouses. In the opinion of the author, the determination of the above group may raise doubts from the point of view of the constitutional principle of equality. Objections also apply to the proposed principle of publishing address data, the information about the location of the property and the information enabling the identification of the movable property of the person submitting the declaration. Publication of such statements in the Public Information Bulletin raises serious constitutional doubts.

Keywords: constitution, property declarations, public function, bill

Ekspert ds. legislacji BAS . irena.galinska-raczy@sejm.gov.pl •

https://orcid.org/0000-0003-3586-0126

\section{Zakres podmiotowy projektu a zasada równości}

1. W projekcie przewidziano dodanie ust. 1a w art. 10 ustawy z 21 sierpnia $1997 \mathrm{r}$. o ograniczeniu prowadzenia działalności gospodarczej przez osoby pełniące funkcje publiczne (t.j. Dz.U. 2017, poz. 1393, ze zm.; dalej: ustawa antykorupcyj-

1 Ocena zgodności z Konstytucja RP poselskiego projektu ustawy o ograniczeniu prowadzenia działalności gospodarczej przez osoby petniące funkcje publiczne sporzadzona 22 lipca 2019 r. na zlecenie Szefa Kancelarii Sejmu; BAS-WAP-1249/19. 
na). Zgodnie z tym przepisem oświadczenia majątkowe osób pełniących następujące funkcje:

- Prezydenta RP,

- Marszałka i wicemarszałka Sejmu,

- Marszałka i wicemarszałka Senatu,

- Prezesa i wiceprezesa Rady Ministrów,

- ministra

odnosiłyby się nie tylko do majątków osobistych tych osób i majątku objętego małżeńską wspólnością majątkową (jak jest obecnie), ale również do majątków osobistych ich małżonków².

2. Przyjęty zakres podmiotowy osób objętych proponowaną ustawą budzi wątpliwości, ponieważ w uzasadnieniu do projektu mowa o „najważniejszych osobach pełniących funkcje publiczne”, ale nie wskazano kryteriów, które uzasadniałyby ten wybór ${ }^{3}$.

Tymczasem ustawa z 31 lipca 1981 r. o wynagrodzeniu osób zajmujących kierownicze stanowiska państwowe (t.j. Dz.U. 2019, poz. 152) nie dokonuje podziału tych stanowisk ze względu na ich „ważność", podobnie jak rozporządzenie Prezydenta Rzeczypospolitej Polskiej z 25 stycznia 2002 r. w sprawie szczegółowych zasad wynagradzania osób zajmujących kierownicze stanowiska państwowe (Dz.U. nr 10, poz. 91, ze zm.). Z drugiej strony w literaturze $e^{4}$ przyjęto, że dla potrzeb związanych $\mathrm{z}$ ustalaniem wynagrodzeń akt ten wyróżnia na podstawie kryterium hierarchii stanowisk w systemie organów władzy państwowej następujące kategorie stanowisk państwowych:

- Prezydenta Rzeczypospolitej Polskiej,

- Marszałka Sejmu, Marszałka Senatu, Prezesa Rady Ministrów, wicemarszałka Sejmu, wicemarszałka Senatu, wiceprezesa Rady Ministrów, Prezesa Najwyższej Izby Kontroli, ministra, Prezesa Narodowego Banku Polskiego, Rzecznika Praw Obywatelskich, Rzecznika Praw Dziecka, Rzecznika Finansowego, Rzecznika Małych i Średnich Przedsiębiorców, Prezesa Urzędu Ochrony Danych Osobowych, Prezesa Instytutu Pamięci Narodowej - Komisji Ścigania Zbrodni przeciwko Narodowi Polskiemu, Przewodniczącego Krajowej Rady Radiofonii i Telewizji, wiceprezesa Najwyższej Izby Kontroli, Szefa Kancela-

2 Ustawą z 17 czerwca 2004 r. o zmianie ustawy - Kodeks rodzinny i opiekuńczy oraz niektórych innych ustaw (Dz.U. nr 162, poz. 1691) zmieniono art. 33 tego Kodeksu, zastępując określenie „majątek odrębny” określeniem „majątek osobisty”. Projekt nie uwzględnia tej zmiany i posługuje się pojęciem: „majątek odrębny”.

3 W uzasadnieniu stwierdzono, że projekt ma na celu: wprowadzenie zasady zgodnie $z$ którą majątki odrębne małżonków również podlegają ujawnieniu w oświadczeniu majątkowym najważniejszych osób pełniących funkcje publiczne. Z tego powodu projekt zawęża krąg tych osób do Prezydenta, Marszałka Sejmu i wicemarszałka Sejmu [...].

4 A. Dral, Sytuacja prawna osób zatrudnionych na kierowniczych stanowiskach państwowych - uwagi de lege lata i de lege ferenda, http://www.wspia.eu/file/15644/05-Dral.pdf. 
rii Sejmu, Szefa Kancelarii Senatu, zastępcy Szefa Kancelarii Sejmu, zastępcy Szefa Kancelarii Senatu, Szefa Kancelarii Prezesa Rady Ministrów, Szefa Służby Cywilnej, Głównego Inspektora Pracy, zastępcy Głównego Inspektora Pracy, Kierownika Krajowego Biura Wyborczego,

- ministra stanu, Szefa Kancelarii Prezydenta, zastępcy Szefa Kancelarii Prezydenta, zastępcy Prokuratora Generalnego,

- Prezesa Polskiej Akademii Nauk, sekretarza stanu, członka Krajowej Rady Radiofonii i Telewizji, pierwszego zastępcy Prezesa Narodowego Banku Polskiego, podsekretarza stanu (wiceministra), wiceprezesa Narodowego Banku Polskiego, zastępcy Rzecznika Praw Obywatelskich, zastępcy Rzecznika Praw Dziecka, zastępcy Prezesa Urzędu Ochrony Danych Osobowych, zastępcy Rzecznika Finansowego, zastępcy Rzecznika Małych i Średnich Przedsiębiorców, kierownika urzędu centralnego, wiceprezesa Polskiej Akademii Nauk, wojewody, zastępcy kierownika urzędu centralnego, wicewojewody ${ }^{5}$.

Jeśli kierować się kolejnością wymieniania tych stanowisk (w obu powołanych aktach prawnych) i wysokością przysługujących na tych stanowiskach wynagrodzeń, to proponowanej ustawie powinien podlegać również np. Prezes NIK (jako stanowisko z wyższym wynagrodzeniem, wymienione przed stanowiskiem „minister”) albo Rzecznik Praw Obywatelskich (którego wynagrodzenie jest takie samo jak wynagrodzenie ministra).

W zakresie podmiotowym proponowanej ustawy pominięto pozostałe osoby należące do grupy osób zajmujących kierownicze stanowiska państwowe określonej ustawą z 31 lipca 1981 r. o wynagrodzeniu osób zajmujących kierownicze stanowiska państwowe ${ }^{6}$ (w tym np. stanowisko Prezesa i wiceprezesa Prokuratorii Generalnej Rzeczypospolitej Polskiej oraz stanowisko „kierownik urzędu

$5 \quad$ Wyliczenie kierowniczych stanowisk państwowych dokonane przez A. Drala zostało uaktualnione do obecnego brzmienia art. 2 ustawy.

6 W myśl art. 2 tego aktu: Ustawa ustala zasady wynagradzania osób zajmujących kierownicze stanowiska państwowe:

1) Prezydenta Rzeczypospolitej Polskiej;

2) Marszałka Sejmu, Marszałka Senatu, Prezesa Rady Ministrów, wicemarszałka Sejmu, wicemarszałka Senatu, wiceprezesa Rady Ministrów, Prezesa Najwyższej Izby Kontroli, ministra, Prezesa Narodowego Banku Polskiego, Rzecznika Praw Obywatelskich, Rzecznika Praw Dziecka, Rzecznika Finansowego, Rzecznika Małych i Średnich Przedsiębiorców, Prezesa Urzędu Ochrony Danych Osobowych, Prezesa Instytutu Pamięci Narodowej - Komisji Ścigania Zbrodni przeciwko Narodowi Polskiemu, Przewodniczacego Krajowej Rady Radiofonii i Telewizji, wiceprezesa Najwyższej Izby Kontroli, Szefa Kancelarii Sejmu, Szefa Kancelarii Senatu, zastępcy Szefa Kancelarii Sejmu, zastępcy Szefa Kancelarii Senatu, Szefa Kancelarii Prezesa Rady Ministrów, Szefa Stużby Cywilnej, Głównego Inspektora Pracy, zastępcy Głównego Inspektora Pracy, Kierownika Krajowego Biura Wyborczego; 
centralnego", o których mowa w powołanym rozporządzeniu Prezydenta RP z 25 stycznia 2002 r.).

3. Proponowane w projekcie określenie zakresu podmiotowego będzie skutkować powstaniem zróżnicowania w zakresie ochrony prawa do prywatności osób zajmujących kierownicze stanowiska państwowe (granice ochrony tej prywatności wyznacza art. 47 i art. 51 ust. 2 Konstytucji RP oraz wynikający z art. 30 Konstytucji RP nakaz respektowania godności) i stosowania wobec tych osób zasad jawności (z uwagi na art. 61 ust. 1 Konstytucji RP).

Skutkiem przyjęcia takiego rozwiązania może być niejednolite traktowanie osób pełniących kierownicze stanowiska państwowe w obszarze zakresu przedmiotowego składanych przez nich oświadczeń o stanie majątkowym, jak również w zakresie określenia granic jawności tych oświadczeń ${ }^{7}$ W obecnym stanie prawnym, co do zasady, oświadczenia o stanie majątkowym tych osób nie są jawne (stanowią tajemnicę prawnie chronioną) - poza wyjątkiem uczynionym w art. 10 ust. 3 ustawy antykorupcyjnej na rzecz Prezesa Naczelnego Sądu Administracyjnego, Pierwszego Prezesa Sądu Najwyższego, Prezesa Narodowego Banku Polskiego, wiceprezesów Narodowego Banku Polskiego ${ }^{8}$. Jednocześnie zgodnie $\mathrm{z}$ art. 10 ust. 3a tej ustawy niektóre $\mathrm{z}$ informacji zawartych $\mathrm{w}$ jawnych oświadczeniach wymienionych osób nie są publikowane w Biuletynie Informacji Publicznej (BIP) 9 (chodzi o dane adresowe, informacje o miejscu położenia nieruchomości, a także informacje umożliwiające identyfikację ruchomości).

3) Ministra Stanu, Szefa Kancelarii Prezydenta, zastępcy Szefa Kancelarii Prezydenta, zastępcy Prokuratora Generalnego;

4) Prezesa Polskiej Akademii Nauk, sekretarza stanu, członka Krajowej Rady Radiofonii i Telewizji, pierwszego zastępcy Prezesa Narodowego Banku Polskiego, podsekretarza stanu (wiceministra), wiceprezesa Narodowego Banku Polskiego, Zastępcy Rzecznika Praw Obywatelskich, Zastępcy Rzecznika Praw Dziecka, Zastępcy Prezesa Urzędu Ochrony Danych Osobowych, Zastępcy Rzecznika Finansowego, zastępcy Rzecznika Małych i Średnich Przedsiębiorców, kierownika urzędu centralnego, wiceprezesa Polskiej Akademii Nauk, wojewody, zastępcy kierownika urzędu centralnego, wicewojewody.

7 Zob. art. 10 ust. 3 oraz ust. 3a ustawy antykorupcyjnej.

$8 \quad$ Informacje zawarte $w$ oświadczeniu o stanie majątkowym, $z$ wyjątkiem oświadczenia złożonego przez Prezesa Naczelnego Sąu Administracyjnego, Pierwszego Prezesa Sądu Najwyższego, Prezesa Narodowego Banku Polskiego, wiceprezesów Narodowego Banku Polskiego oraz osoby, o których mowa w art. 2 pkt $6 d$, stanowia tajemnice prawnie chroniona i podlegaja ochronie przewidzianej dla informacji niejawnych o klauzuli tajności „zastrzeżone”, określonej w przepisach o ochronie informacji niejawnych, chyba że osoba, która złożyła oświadczenie, wyraziła pisemna zgodę na ich ujawnienie. W szczególnie uzasadnionych przypadkach osoba uprawniona, zgodnie z ust. 4, 5 lub 6, do odebrania oświadczenia może je ujawnić pomimo braku zgody składającego oświadczenie. Oświadczenie przechowuje się przez 6 lat.

9 O publikacji w BIP tych oświadczeń stanowi art. 10 ust. 3b ustawy antykorupcyjnej: Jawne informacje zawarte $w$ oświadczeniach o stanie majątkowym, o których mowa 
Według ocenianego projektu jawne byłyby wszystkie informacje podawane w oświadczeniach majątkowych składanych np. przez Prezydenta RP (w tym również np. dane adresowe zamieszkania i położenia nieruchomości). Oświadczenia te wraz $\mathrm{z}$ wymienionymi danymi byłyby publikowane w BIP. Co istotne, projektodawcy nie przewidzieli możliwości niepublikowania oświadczenia w BIP, jak ma to miejsce w przypadku określonym w art. 10 ust. 3a ustawy antykorupcyjnej ${ }^{10}$. Jednocześnie tylko osoby, o których mowa w projekcie, byłyby zobowiązane ujawniać majątek osobisty swoich małżonków.

4. Określony w ten sposób w projekcie zakres podmiotowy budzi wątpliwości co do zasady równości (art. 32 ust. 1 Konstytucji) w grupie, którą można kwalifikować jako „osoby zajmujące kierownicze stanowiska państwowe” ${ }^{11}$, jak również z punktu widzenia transparentności życia publicznego w demokratycznym państwie (art. 61 ust. 1 Konstytucji).

Tymczasem, jak wynika $\mathrm{z}$ orzecznictwa Trybunału Konstytucyjnego, konstytucyjna zasada równości wobec prawa polega na tym, że wszystkie podmioty

$w$ ust. $3 a$, osoba odbierająca oświadczenia udostępnia $w$ Biuletynie Informacji Publicznej, o którym mowa $w$ ustawie $z$ dnia 6 września 2001 r. o dostępie do informacji publicznej (Dz.U. z 2016 r. poz. 1764 oraz z 2017 r. poz. 933), nie później niż do dnia 30 czerwca każdego roku.

10 Informacje zawarte $w$ oświadczeniu o stanie majątkowym złożonym przez Prezesa $\mathrm{Na}$ czelnego Sadu Administracyjnego, Pierwszego Prezesa Sądu Najwyższego, Prezesa Narodowego Banku Polskiego, wiceprezesów Narodowego Banku Polskiego oraz osoby, o których mowa wart. 2 pkt $6 d$, sa jawne także co do imienia i nazwiska, $z$ wyjatkiem danych adresowych, informacji o miejscu położenia nieruchomości, a także informacji umożliwiających identyfikację ruchomości osoby składającej oświadczenie. Na wniosek osoby składającej oświadczenie osoba odbierająca oświadczenie może zdecydować o objęciu informacji zawartych $w$ oświadczeniu ochrona przewidziana dla informacji niejawnych o klauzuli tajności „zastrzeżone”, określona w przepisach ustawy z dnia 5 sierpnia 2010 r. o ochronie informacji niejawnych (Dz.U. z 2018 r.poz. 412, 650, 1000, 1083 i 1669 oraz z 2019 r. poz. 125), jeżeli ujawnienie tych informacji mogłoby powodować zagrożenie dla składającego oświadczenie lub osób dla niego najbliższych. Minister Sprawiedliwości jest uprawniony do zniesienia tej klauzuli. W stosunku do tego uprawnienia przepisu art. 6 ust. 3 ustawy z dnia 5 sierpnia 2010 r. o ochronie informacji niejawnych nie stosuje się.

11 Trybunał Konstytucyjny mówił o kryterium wyróżnienia klasy podmiotów objętych ustawą antykorupcyjną jako osobach pełniących wysokie funkcje publiczne (wyrok TK z 23 czerwca 1999 r., sygn. akt K 30/98, OTK 1999, nr 5, poz. 101). TK zwraca również uwagę na argument uzasadniający wprowadzenie ograniczeń, jakim jest szczególne wyczulenie opinii publicznej na sposób postępowania osób zajmujących kierownicze stanowiska państwowe, co jednocześnie związane jest z większymi możliwościami uzyskiwania przez te osoby różnego rodzaju przywilejów. Dodatkowo wskazuje na szczególną łatwość pojawiania się konfliktu interesów, gdy poszczególne funkcje pełnione przez tę samą osobę popadają ze sobą w kolizję (uchwała TK z 11 stycznia 1995 r., sygn. akt W 17/94, OTK 1995, nr 1, poz. 18). 
prawa (adresaci norm prawnych) charakteryzujace się dana cecha istotna (relewantna) w równym stopniu, maja być traktowane równo. A więc według jednakowej miary, bez różnicowań zarówno dyskryminujących, jak i faworyzujących ${ }^{12}$. Status prawny osób pozostających na kierowniczych stanowiskach państwowych pozwala na wyróżnienie tej grupy spośród szerszej grupy, jaką stanowią osoby pełniące funkcje publiczne ${ }^{13}$.

Przyjęte w projekcie zróżnicowanie w grupie osób zajmujących kierownicze stanowiska państwowe w zakresie składania oświadczeń nie zostało w wystarczający sposób umotywowane przez projektodawców, ponieważ nie określono kryteriów kwalifikowania do kategorii „najważniejsze osoby pełniące funkcje publiczne". W związku z tym nie można przyjętego zróżnicowania ocenić jako uzasadnionego w stopniu wystarczającym dla pozytywnej oceny w kontekście zasady równości.

5. Proponowane zróżnicowanie sytuacji prawnej w grupie osób zaliczanych do „kierowniczych stanowisk państwowych” zarówno w zakresie rozszerzenia danych podawanych w oświadczeniu (o dane dotyczące majątku osobistego małżonków), jak i w zakresie upubliczniania tych oświadczeń, budzi uzasadnione wątpliwości z punktu widzenia zasady równości (art. 32 ust. 1 Konstytucji RP), tym bardziej że $w$ ramach ostatniej nowelizacji ustawy antykorupcyjnej została wprowadzona regulacja, zgodnie z którą stały się jawne oświadczenia o stanie majątkowym Prezesa Naczelnego Sądu Administracyjnego, Pierwszego Prezesa Sądu Najwyższego, Prezesa Narodowego Banku Polskiego, wiceprezesów Narodowego Banku Polskiego, a nawet pracowników NBP wskazanych w art. 2 pkt $6 \mathrm{~d}^{14}$ (ci ostatni nie mieszczą się w grupie kierowniczych stanowisk państwowych).

Omawiane zróżnicowanie sprawia, że w grupie osób zajmujących kierownicze stanowiska państwowe znajdują się i zgodnie z projektem znajdą się takie osoby, których oświadczenia majątkowe będą podlegać ochronie ze względu na konstytucyjne prawo do ochrony prywatności i autonomii informacyjnej jednostki, a nade wszystko wynikającą $z$ art. 10 ust. 3 ustawy antykorupcyjnej zasadę niejawności oświadczeń ${ }^{15}$, oraz takie, których oświadczenia będą należeć do

12 Wyrok TK z 20 listopada 2002 r., sygn. akt K 41/02, i powołane tam orzeczenia.

13 Zob. A. Dral, Sytuacja prawna osób zatrudnionych, op. cit., oraz J. Stelina, Stosunki pracy osób pełniących funkcje organów państwa, Warszawa 2016.

14 Chodzi o pracowników Narodowego Banku Polskiego zajmujących stanowiska dyrektora oddziału okręgowego, dyrektora departamentu (komórki równorzędnej) i ich zastępców oraz osób zajmujących stanowiska równorzędne pod względem płacowym ze stanowiskiem dyrektora departamentu i jego zastępcy.

15 Informacje zawarte $w$ oświadczeniu o stanie majątkowym, $z$ wyjątkiem oświadczenia złożonego przez Prezesa Naczelnego Sądu Administracyjnego, Pierwszego Prezesa Sądu Najwyższego, Prezesa Narodowego Banku Polskiego, wiceprezesów Narodowego Banku Polskiego oraz osoby, o których mowa w art. 2 pkt $6 d$, stanowią tajemnicę prawnie chroniona i podlegaja ochronie przewidzianej dla informacji niejawnych o klauzuli tajności 
informacji kwalifikowanych jako informacje należące do zakresu konstytucyjnego prawa dostępu do informacji publicznej ${ }^{16}$.

Projektowane rozwiązanie - poza tym, że tworzy nierównoprawne zasady w zakresie ochrony prywatności osób zajmujących kierownicze stanowiska państwowe i ich małżonków - nie „wpisuje się” w realizację zgłaszanych od dawna w literaturze postulatów, by poszerzać m.in. jawność oświadczeń o stanie majątkowym (w ramach dostępu do informacji publicznej) ${ }^{17}$.

6. Dla negatywnej oceny w zakresie zasady równości istotne znaczenie ma również brak jednoznacznej motywacji projektodawców dla wykazywania i ujawniania w BIP majątków osobistych małżonków takich osób, jak np. Marszałek Senatu RP czy minister. Zawarte w uzasadnieniu projektu stwierdzenie, że: $w$ ostatnim czasie $w$ przestrzeni medialnej pojawiło się wiele informacji o majątkach odrębnych małżonków osób pełniących funkcje publiczne nie odnosi się do: „najwyższych stanowisk kierowniczych” w państwie, ale w ogóle do osób pełniących funkcje publiczne i ich małżonków, czyli do grupy znacznie szerszej niż osoby pełniące kierownicze stanowiska państwowe.

\section{Wprowadzenie jawności oświadczeń majątkowych osób wymienionych $\mathbf{w}$ art. 1 projektu}

1. Odnosząc się do zagadnienia jawności i upubliczniania w BIP oświadczeń majątkowych (będącego najbardziej „zaawansowaną” formą jawności) osób wymienionych w art. 1 projektu, należy dokonać analizy aspektu kolizji dwóch norm konstytucyjnych, jakimi są prawo do ochrony życia prywatnego (prywatności) i ochrony danych osobowych (art. 47 i art. 51 Konstytucji RP) ${ }^{18}$ oraz prawo do informacji m.in. „o dzia-

„zastrzeżone”, określonej w przepisach o ochronie informacji niejawnych, chyba że osoba, która złożyła oświadczenie, wyraziła pisemną zgodę na ich ujawnienie. W szczególnie uzasadnionych przypadkach osoba uprawniona, zgodnie z ust. 4, 5 lub 6, do odebrania oświadczenia może je ujawnić pomimo braku zgody składającego oświadczenie. [...]

16 M. Wild w komentarzu do art. 61 Konstytucji [w:] Konstytucja RP, t. I, Komentarz. Art. 1-86, red. M. Safjan, L. Bosek, Warszawa 2016, stwierdza: te same dane, jak np. informacje o sytuacji majątkowej osób petniących funkcje publiczne, moga należeć bądź do zakresu konstytucyjnego prawa dostępu do informacji publicznej (jak to ma miejsce w odniesieniu od osób zobowiązanych do składania publikowanych oświadczeń majątkowych), bądź też podlegać ochronie ze względu na konstytucyjne prawo do ochrony prywatności $i$ autonomii informacyjnej jednostki (jak to ma miejsce w odniesieniu do innych osób).

17 W ten sposób: M. Jabłoński, K. Wygoda, Ustawa o dostępie do informacji publicznej. Komentarz, Wrocław 2002, s. 130.

18 R. Piotrowski, Prawo do prywatności i ochrony danych osobowych jako wartości konstytucyjne [w:] Prywatność a jawność. Bilans 25-lecia i perspektywy na przyszłość, red. A. Mednis, Warszawa 2016, zauważa, że: [w] orzecznictwie TK znajduje odzwiercied- 
łalności organów władzy publicznej oraz osób pełniących funkcje publiczne” (wynikające z art. 61 Konstytucji RP czy też szerzej z zasady jawności życia publicznego).

W doktrynie stwierdza się, że w świetle orzecznictwa i praktyki stosowania Konstytucji RP prawo do prywatności i ochrony danych osobowych nie mają charakteru absolutnego ${ }^{19}$, zwłaszcza kiedy ograniczenia tego prawa dotyczą osób pełniących funkcje publiczne.

Według Trybunału Konstytucyjnego osoby pełniące funkcje publiczne: $z e$ względu na prawo obywateli do uzyskiwania informacji o działalności organów władzy publicznej, musza się liczyć z obowiązkiem ujawnienia przynajmniej niektórych aspektów swego życia prywatnego (wyrok TK w sprawie o sygn. akt K 20/03). Takim ujawnieniem życia prywatnego jest m.in. wykazywanie stanu majątkowego w ramach obowiązku składania oświadczeń o stanie majątkowym oraz publikowanie tych oświadczeń w BIP.

Jednocześnie w literaturze podkreśla się, że w stosunku do osób publicznych orzecznictwo dopuszcza znacznie szerszy zakres ingerencji w sferę życia prywatnego niż w stosunku do innych podmiotów, tj. osób nieprowadzących działalności publicznej, a zarazem, że judykatura uznaje, iż: [...] ustawodawcy przysługuje swoboda $w$ nakładaniu ograniczeń na osoby petniace funkcje publiczne, np. $w$ celu zwalczania korupcji. Ograniczenia te musza być racjonalnie związane z chronionym interesem i być wspótmierne z jego rangą. Należy je traktować nie jako ograniczenia praw lub wolności tych osób, lecz jako środki zapewniające prawidłowe funkcjonowanie instytucji publicznych [zob. wyr. TK $z$ 8.10.2001 r., K 11/01, OTK-A 2001, Nr 7, poz. 210, cz. III, pkt 3; wyr. TK z 6.12.2005 r., SK 7/05, Dz.U. z 2005 r. Nr 246, poz. 2092, cz. III, pkt 4 oraz wyr. TK z 12.5.2008 r., SK 43/05, Dz.U. z 2008 r. Nr 90, poz. 560, cz. III, pkt 9.4.]. Do takich środków można zaliczyć obowiązek podania informacji o swoim stanie majątkowym (uzyskiwane dochody, ich wysokośc, źródła itp.) i upublicznienia ich (np. publikacja w Biuletynie Informacji Publicznej lub wpis do tzw. rejestru korzyści majątkowych), co stanowi ingerencje w sfere życia prywatnego $i w$ autonomię informacyjna jednostki [zob. wyr. TK z 6.12.2005 r., SK 7/05, Dz.U. z 2005 r. Nr 246, poz. 2092, cz. III, pkt 4 i 5 oraz powołane tam orzecznictwo $]^{20}$.

lenie interpretacja ustawy zasadniczej identyfikująca jako identyczna wartość konstytucyjna sferę chroniona przez prawo do ochrony prywatności (art. 47 Konstytucji) oraz ochrony danych osobowych (art. 51 Konstytucji), a także prawo do ochrony tajemnicy komunikowania się (art. 49 Konstytucji), obejmującej „wszelkiego rodzaju kontakty międzyosobowe" [Tak w uzasadnieniu wyr. TK z 30.7.2014 r., K 23/11, Dz.U. z 2014 r. poz. 1055]. Wartościa ta jest - według TK - sfera prywatności [Ibidem], w której jednostce przystuguje konstytucyjnie gwarantowana wolność przekazywania i pozyskiwania informacji, $w$ tym udostępniania informacji o sobie samej.

19 W ten sposób R. Piotrowski, Prawo do prywatności, op. cit.

20 W ten sposób J. Karczewski, T. Stawecki, Prywatność i jawność - ważenie zasad prawnych [w:] Prywatność a jawność. Bilans 25-lecia i perspektywy na przyszłość, red. A. Mednis, Warszawa 2016. 
Dla rozważanego aspektu kolizji między zasadą ochrony życia prywatnego osób zajmujących kierownicze stanowiska państwowe a zasadą jawności życia publicznego znamienne wydaje się następujące stanowisko Trybunału Konstytucyjnego (przyjęte w wyroku sprawy o sygn. akt SK 7/05 ${ }^{21}$ ): [...] w odniesieniu do osób petniących funkcje publiczne, ingerencja $w$ sferę życia prywatnego może być znacznie głębsza, niż to ma miejsce w stosunku do innych osób. Granice ingerencji wytyczaja jednak kryteria wskazane $w$ art. 31 ust. 3 Konstytucji. Koreluje $z$ nimi kryterium „niezbędności” przywołane $w$ art. 51 ust. 2 Konstytucji. Ograniczenie ochrony prawa do prywatności należy przy tym rozpatrywać w kontekście prawa do uzyskiwania informacji (art. 61 Konstytucji).

Treści art. 61 Konstytucji odpowiada art. 5 ust. 2 ustawy z 6 września 2001 r. o dostępie do informacji publicznej (Dz.U. Nr 112, poz. 1198 ze zm.) przewidujący, że prawo do informacji publicznej podlega ograniczeniu ze względu na prywatność osoby fizycznej lub tajemnice przedsiębiorcy. Ograniczenie to nie dotyczy jednak informacji o osobach petniacych funkcje publiczne, majacych zwiazek z petnieniem tych funkcji. Związek przedmiotu informacji z wypetnianiem funkcji publicznej musi być wyraźny i rzeczywisty, ale nie musi być bezpośredni (zob. W. Sokolewicz, (w:) Konstytucja Rzeczypospolitej Polskiej. Komentarz, Warszawa 2005, komentarz do art. 61). Nowe informacje zamieszczane w oświadczeniach majątkowych, dotyczące dochodów osiąganych z tytułu zatrudnienia lub innej działalności zarobkowej, wskazując ich źródło i wysokość, pozwalają stwierdzić, czy działania radnych nie wynikają z ich materialnej zależności od osób lub instytucji, na których interesy maja wpływ decyzje rady.

W ocenie Trybunału Konstytucyjnego jawność oświadczeń majątkowych umożliwia ich skuteczniejsza kontrolę. Każdy z wyborców może sprawdzić, czy majątek radnego wzrósł $w$ ciagu ostatniego roku, a jeśli tak, to czy odpowiada osiaganym dochodom. Z kolei przewodniczący rady gminy, któremu radny obowiązany jest dostarczyć wraz z oświadczeniem majątkowym kopie zeznania o wysokości osiagniętego dochodu z roku podatkowego (PIT) za rok poprzedni i jego korekta, powinien dokonać realnej analizy danych zawartych w oświadczeniu $i w$ terminie do 30 października każdego roku przedstawić radzie gminy stosowne informacje (art. 24h ust. 7 SamGminU [ustawy o samorządzie gminnym - dopisek I.G.-R.]). Ponadto

${ }^{21}$ W wyroku tym TK oceniał wprowadzenie do oświadczeń majątkowych składanych przez radnych (na podstawie art. 24h ust. 1 pkt 2 ustawy o samorządzie gminnym) informacji o dochodach osiąganych z tytułu zatrudnienia lub innej działalności zarobkowej lub zajęć oraz uzyskania przez te informacje przymiotu jawności (z uwagi na to, że stały się one jednym z punktów jawnych oświadczeń majątkowych). Przed tą nowelizacją informacje podane w oświadczeniu stanowiły tajemnicę służbową; mogły zostać ujawnione w przypadku pisemnej zgody radnego oraz - w szczególnie uzasadnionych przypadkach - przez przewodniczącego rady, po zasięgnięciu opinii komisji rewizyjnej. 
równoległą kontrolę tych danych będa prowadzić urzędy skarbowe. Wszystkie te działania mają stużyć walce $z$ korupcją. [...]

Trybunat Konstytucyjny, badając zakwestionowane przepisy, doszedt do przekonania, że nowe uregulowania dotyczące oświadczeń majątkowych radnych mieszcza się także w granicach zgodnych $z$ konstytucyjna zasada proporcjonalności. Przyjęte rozwiązania nie tylko „sprzyjaja”" zakładanym celom, ale sa niezbędne dla efektywnego przeciwdziałania zjawiskom o charakterze korupcyjnym. Porównując korzyści, jakie może przynieść oceniana regulacja $w$ walce $z$ korupcja, i skutek $w$ postaci ograniczenia konstytucyjnych praw osób, do których się odnosi, Trybunał Konstytucyjny stwierdza, że w jej kształtowaniu została zachowana zasada proporcjonalności. Obowiązujące w porządku prawnym przepisy ustaw zwyklych, regulujace w sposób konkretny (i uzupetniający wobec ustawy zasadniczej) określone dziedziny życia publicznego w państwie, stanowią rozwinięcie konstytucyjnej zasady jawności zycia publicznego (por. wyrok SN z 1 czerwca 2000 r., sygn. akt III RN 64/00, OSNP nr 6/2001, poz. 183). Taka sama rolę petnia zakwestionowane przepisy $y^{22}$.

2. W związku z powyższym stanowiskiem Trybunału Konstytucyjnego oraz dostrzeganą $\mathrm{w}$ doktrynie tendencją obejmowania przez ustawodawstwo coraz szerszego kręgu podmiotów zaostrzonymi regulacjami antykorupcyjnymi w tym ustaloną w odniesieniu do parlamentarzystów i radnych (oraz osób pełniących funkcje organów w samorządzie terytorialnym), zasadą upubliczniania oświadczeń o stanie majątkowym - co do zasady wprowadzenie jawności oświadczeń osób wymienionych $\mathrm{w}$ art. 1 projektu (polegające na zamieszczaniu tych oświadczeń w BIP) w opinii autorki jest dopuszczalne.

W literaturze wskazano na zbieżność wyroku TK w sprawie o sygn. akt $\mathrm{K} 24 / 98^{23} \mathrm{z}$ orzecznictwem i prawem europejskim w rozszerzaniu omawianej

22 Fragmenty uzasadnienia wyroku TK w sprawie o sygn. akt SK 7/05.

23 Wyrok ten odnosił się do art. 1 pkt 9 ustawy z 18 czerwca 1998 r. o zmianie ustawy o ujawnieniu pracy lub służby w organach bezpieczeństwa państwa lub współpracy z nimi w latach 1944-1990 osób pełniących funkcje publiczne oraz o zmianie niektórych innych ustaw w zakresie dotyczącym art. 17 ust. 2. TK stwierdzając zgodność tych przepisów z art. 2, 32, 173 i 178 Konstytucji RP, uznał, że: [...] artykuł 47 Konstytucji RP stanowi, iz każdy ma prawo do prawnej ochrony życia prywatnego oraz do decydowania o swoim życiu osobistym. Jednocześnie jednak przeważa $w$ doktrynie pogląd $w$ myśl którego, w odniesieniu do osób ubiegających się lub pełniących funkcje publiczne, prawo do ochrony prywatności podlega istotnemu ograniczeniu. Zgodnie z tym pogladem, o ile sfera życia intymnego ( $w$ znaczeniu szerszym niż potocznie przyjęte) objęta jest petna prawna ochrona, o tyle ochrona sfery życia prywatnego podlega pewnym ograniczeniom, uzasadnionym "usprawiedliwionym zainteresowaniem”. Jest oczywiste, $\dot{z}$ e osoba kandydująca do petnienia funkcji publicznej, godzić się musi z takim zainteresowaniem opinii publicznej, wyrażajacym się między innymi wola uzyskania jak najszerszego zakresu informacji o jej życiu (również prywatnym) i przeszłości. W szczególności przedmiotem takiego zainteresowania może być, a w polskiej rzeczywistości - 
transparentności w sposób następujący: Stanowisko to jest zbieżne z tendencjami obserwowanymi $w$ orzecznictwie i regulacjach europejskich, które wyraźnie zmierzaja do zagwarantowania możliwie szerokiego dostęp obywatelom do informacji publicznej, nawet kosztem ograniczenia prawa do prywatności osób pełniących funkcje publiczne, gdyż tylko taki dostęp gwarantuje transparentność życia publicznego $w$ demokratycznym państwie ${ }^{24}$.

W wyroku tym Trybunał Konstytucyjny stwierdził, że: Żaden obywatel nie jest zobowiązany do ubiegania się, ani do petnienia funkcji publicznej, zaś znając następstwa tego faktu w postaci upublicznienia pewnego zakresu informacji, należacych do sfery prywatności, podejmuje on samodzielna i świadoma decyzję, oparta na rachunku pozytywnych i negatywnych konsekwencji, wkalkulowując określone ograniczenia, oraz dyskomfort związany $z$ ingerencja $w \dot{z} y c i e$ prywatne.

W doktrynie prezentowane jest stanowisko, że wobec osób pełniących funkcje publiczne wymóg radykalnej przejrzystości jest nie tylko dozwolony, ale wręcz konieczny ${ }^{25}$, a przyczyną uzasadniającą ingerencję w ochronę życia prywatnego takich osób może być dążenie do zwalczania korupcji przez upublicznianie określonych informacji o ich stanie majątkowym (uzyskiwanych dochodach, ich wysokości, źródłach tych dochodów). Jednocześnie jawność oświadczeń majątkowych jest narzędziem rzeczywistej kontroli sprawowanej przez wyborców ${ }^{26}$.

Z powyższych względów prawnych sytuacja, w której oświadczenia majątkowe parlamentarzystów i samorządowców (radnych i osób pełniących funkcje organów takich, jak wójt, prezydent miasta czy osoba wydająca decyzje w imieniu tego organu) są jawne, a nie są jawne (i według projektu nie będą) oświadczenia np. kierownika urzędu centralnego administracji rządowej (wydającego decyzje administracyjne i gospodarującego mieniem publicznym), nie wydaje się czytelna $\mathrm{z}$ punktu widzenia interesu społecznego, jaki można wywodzić z art. 61 Konstytucji w zakresie prawa do uzyskiwania informacji o działalności organów władzy publicznej oraz osób pełniących funkcje publiczne ${ }^{27}$.

jest, fakt współpracy z organami bezpieczeństwa państwa. Uznać należy, że sfera prywatności naruszana jest poprzez sam obowiązek złożenia oświadczenia lustracyjnego, jednakże znajduje to uzasadnienie w przyjętej przez racjonalnego ustawodawcę ogólnej koncepcji lustracji i jest bezpośrednia konsekwencja woli pełnienia funkcji publicznej. Wynikłe z samych założeń lustracji ograniczenie prawa do prywatności, musi być uznane za konieczne w demokratycznym państwie prawa dla jego bezpieczeństwa, zatem za wyczerpujące przesłanki art. 31 ust. 3 Konstytucji RP.

J. Uliasz, Prawo do prywatności osób petniących funkcje publiczne, „Samorząd Terytorialny" 2013, nr 3. Autorka wskazuje liczne przykłady unormowań europejskich w tym zakresie.

25 W ten sposób J. Karczewski, T. Stawecki, Prywatność i jawność, op. cit.

26 Ibidem.

27 Według G. Sibigi, Dostęp do informacji publicznej a prawa do prywatności jednostki i ochrony jej danych osobowych, „Samorząd Terytorialny” 2003, nr 11, oświadczenia 
3. Jawność oświadczeń majątkowych stanowi element kontroli społecznej nad działalnością osób zobowiązanych do ich składania, a dzięki jawnym oświadczeniom każdy obywatel ma możliwość sprawowania kontroli równowagi, jaka winna zachodzić pomiędzy majątkiem nabytym $w$ trakcie petnienia funkcji publicznych a dochodami uzyskanymi w tym okresie. Jawność oświadczeń majątkowych jest także przejawem działań ustawodawcy zmierzajacych do wyeliminowania ryzyka korupcji i zapewnienia przejrzystości działalności organów samorzadu terytorialnego ${ }^{28}$.

Jednocześnie uznaje się, że zasada jawności tych oświadczeń stanowi jeden $\mathrm{z}$ aspektów realizacji konstytucyjnej zasady obywatelskiego prawa do informacji wynikającego z art. 61 ust. 1 Konstytucji ${ }^{29}$.

W literaturze podkreśla się, że składanie jawnych oświadczeń majątkowych ma dwojaki cel. Z jednej strony oświadczenia te są ważnym mechanizmem antykorupcyjnym (pozwalającym na kontrolę stanu majątkowego składających oświadczenia), zaś z drugiej strony mają one wzmacniać zasadę zaufania do osób je składających ${ }^{30}$.

Mając na względzie powyższe, należałoby opowiedzieć się za poglądem, że ustalenie zasady jawności oświadczeń kolejnej grupy osób pełniących funkcje publiczne, jak również publikowanie (upublicznianie) tych oświadczeń w BIP jest dopuszczalne.

\section{Wykazywanie w oświadczeniach o stanie majątkowym majątku osobistego małżonka osoby składającej oświadczenie}

1. Małżonkowie osób zajmujących kierownicze stanowiska państwowe, o których mowa w art. 1 projektu, jako członkowie rodzin osób pełniących funkcje publiczne, należą do „osób prywatnych”, czyli do tych, których sfera prywatności jest chroniona intensywniej niż w przypadku osób pełniących funkcje publiczne ${ }^{31}$.

Osoby takie nie obejmuje obowiązek ujawniania niektórych aspektów życia prywatnego wynikający z art. 61 ust. 1 Konstytucji RP ${ }^{32}$, jednakże w doktrynie dostrzega się, że: $w$ niektórych przypadkach ingerencja w prywatność osób pelniacych funkcje publiczne skutkować będzie nieuchronnie wkroczeniem także w prywatność

o stanie majątkowym należą do informacji ujawnianych w trybie określonym w ustawie o dostępie do informacji publicznej.

28 K. Janaczek, Oświadczenia majątkowe pracowników samorządowych i radnych - zarys problemu $w$ kontekście jawności działania samorzadu terytorialnego [w:] Jawność w samorzadzie terytorialnym, red. B. Dolnicki, Warszawa 2015.

29 Ibidem.

30 J. Juchniewicz, Status radnego gminy [w:] Status prawny rady gminy, red. M. Chmaj, Warszawa 2012, s. 172-175.

31 W ten sposób J. Karczewski, T. Stawecki, Prywatność i jawność, op. cit.

32 Tak: TK w wyroku spraw o sygn. akt K 20/03 oraz K 17/05. 
osób z nimi związanych. W sprawie K 20/03 TK stwierdził, że zobowiązanie do złożenia oświadczenia (zawierającego informację o prowadzonej działalności gospodarczej oraz o zawartych umowach cywilnoprawnych) dotyczacego małżonków funkcjonariuszy samorządowych odpowiada warunkom proporcjonalności, jest zaś z nimi sprzeczne, gdy obejmuje zstępnych, wstępnych i rodzeństwo tych funkcjonariuszy ${ }^{33}$.

W powołanym wyroku ${ }^{34}$ Trybunał Konstytucyjny wyraził następujący pogląd: [...] wspólne pożycie małżonków, a nawet - w przeważającej liczbie przypadków pozostawanie we wspólności majątkowej, powoduje, że wszelkie dobra nabywane przez jednego z małżonków, uzyskiwane przez niego korzyści, wynagrodzenie za prace stanowia o poprawie sytuacji materialnej obojga matżonków, sa przeznaczone do wspólnego korzystania, nawet jeśli małżonkowie znieśli ustrój wspólności ustawowej. W konsekwencji, uzyskanie korzyści przez małżonka funkcjonariusza powinno być traktowane niemal tak samo, jak uzyskanie jej przez samego funkcjonariusza. Zainteresowanie funkcjonariusza uprzywilejowaniem jego małżonka jest na pewno bardzo duże, stąd $i$ duża pokusa ułatwienia małżonkowi nabycia określonego dobra, załatwienia mu dobrej pracy itd..

Jednocześnie w opinii Trybunału Konstytucyjnego zarówno prawo obywateli do informacji, jak i wartość, jaką jest jawność życia publicznego, uprawniają do szerszego niż w przypadku innych podmiotów ingerowania w prawo do prywatności osób pełniących funkcje publiczne, w tym m.in. usprawiedliwienie znajduje ograniczenie prawa do prywatności małżonka osoby pełniącej funkcje publiczną ${ }^{35}$.

Powyższy pogląd prezentowany przez TK odnosił się do art. 24 j ustawy o samorządzie gminnym, którym wprowadzono obowiązek składania oświadczeń

33 M. Laskowska, Prawo do informacji o działalności osób pełniących funkcje publiczne a ich prawo do ochrony prawnej życia prywatnego. Refleksje na tle orzecznictwa TK [w:] Obywatelskie prawo do informacji, red. T. Gardocka, Warszawa 2008.

34 Wyrok z 13 lipca 2004 r., sygn. akt K 20/03, w którym TK przyjął, że wprowadzony kwestionowanymi przepisami obowiązek składania oświadczeń i informowania o sytuacji małżonka funkcjonariusza mieści się w granicach zasady proporcjonalności i nie narusza przepisów Konstytucji.

35 J. Uliasz, komentując wyrok TK o sygn. akt K 20/03, cytuje następujący jego fragment: usprawiedliwienie znajduje ograniczenie prawa do prywatności małżonka osoby petniącej funkcję publiczną, gdyz:

a) pozostawanie $w$ związku małżeńskim jest okolicznościa znanq otoczeniu, w konsekwencji czego nie można mówić w tym przypadku o ujawnianiu powiązań rodzinnych wbrew woli zainteresowanego,

b) w przeważającej liczbie przypadków małżonkowie pozostają we wspólności majątkowej $i$ wspólnie korzystaja $z$ dóbr nabywanych przez jednego $z$ matżonków, dlatego uzyskanie korzyści przez matżonka funkcjonariusza powinno być traktowane niemal tak samo, jak uzyskanie jej przez samego funkcjonariusza (w konsekwencji składanie oświadczeń o sytuacji majątkowej małżonka funkcjonariusza mieści się w granicach zasady proporcjonalności), idem, Prawo do prywatności, op. cit. 
o działalności gospodarczej prowadzonej przez małżonka m.in. radnego i wójta. Oświadczenia te odnosiły się do małżonków bez względu na ustrój majątkowy, w jakim pozostawali oni z osobami pełniącymi mandat czy funkcję w samorządzie.

Warto dodać, że również $\mathrm{w}$ innych przepisach ustawodawca wymaga, by osoby pełniące funkcje publiczne ujawniały dane odnoszące się do majątków osobistych małżonków bez względu na to, czy np. osoba zgłaszająca informacje do Rejestru korzyści pozostaje w małżeńskiej wspólności majątkowej czy w rozdzielności ${ }^{36}$. W literaturze podkreśla się doniosłe znaczenie m.in. ujawniania danych do Rejestru korzyści jako stanowiących kontrolę interesów majątkowych osób je składających ${ }^{37}$.

Wskazane unormowania stanowią niewątpliwie ingerencję $\mathrm{w}$ sferę prywatności małżonków osób pełniących funkcje publiczne, ale nie są kwestionowane z punktu widzenia zasad wynikających z Konstytucji RP (w tym w zakresie art. 47). W piśmiennictwie wyrażane jest natomiast stanowisko co do nieskuteczności tego instrumentu zapobiegania korupcji ${ }^{38}$.

2. Proponowany w projekcie mechanizm ujawniania przez osoby pełniące określone kierownicze stanowiska państwowe w oświadczeniu majątkowym informacji dotyczących majątku osobistego ich małżonków i upubliczniania tych informacji poprzez publikowanie oświadczeń w BIP, może budzić wątpliwości związane z tym, że np. w ramach ukształtowania rozdzielności majątkowej przez małżonków (art. 50 i art. $51^{1}$ Kodeksu rodzinnego i opiekuńczego) każdy z nich może samodzielnie zarządzać swoim majątkiem $\mathrm{z}$ wyłączeniem drugiego małżonka (ponieważ będą istniały tylko dwa osobiste majątki każdego z małżonków) ${ }^{39}$.

36 Takie unormowania zawarto w art. 35a ustawy z 9 maja 1996 r. o wykonywaniu mandatu posła i senatora oraz $\mathrm{w}$ art. 12 ustawy antykorupcyjnej.

37 W ten sposób A. Bobiec, Informacja publiczna a ochrona prywatności osób pelniących funkcje publiczne [w:] Jawność w samorządzie terytorialnym, red. B. Dolnicki, Warszawa 2015.

38 Na przykład A. Rzetecka-Gil stwierdza: Charakterystyczne jest, że obowiązek określony tym przepisem stanowi typowa lex imperfecta, bowiem niezgłoszenie korzyści do Rejestru korzyści nie podlega żadnym sankcjom. Ustawodawca nie określit konsekwencji (nie przewidział sankcji) wynikających z: niezłożenia informacji o uzyskanych korzyściach; złożenia tej informacji po terminie.

$W$ literaturze podnosi się, że osłabia to skuteczność tej instytucji (A. Szewc, T. Szewc, Wójt, burmistrz..., s. 66). Skutki nierespektowania normy określonej w tym przepisie przejawiać się więc moga raczej w płaszczyźnie moralno-etycznej (potępienie moralne, bojkot towarzyski) bądź politycznej (konieczność rezygnacji ze stanowiska lub funkcji) aniżeli prawnej, eadem, Ustawa o ograniczeniu prowadzenia działalności gospodarczej przez osoby pełniące funkcje publiczne. Komentarz, 2009, LEX.

39 A. Brzezińska stwierdza, że: $w$ razie umownego wyłaczenia wspólności ustawowej lub umownej $w$ czasie trwania małżństwa:

1) małżonkowie przestaja tworzyć majątek wspólny na przyszłość i staja się podmiotami dwóch oddzielnych majątków - w ten sposób, że każde z nich zachowuje zarówno 
Jak podkreśla się w literaturze: [w] preferowanym przez ustawodawcę ustroju wspólności ustawowej centralne miejsce zajmuje majątek wspólny. Prawodawca zadbał jednak o to, aby każdy z małżonków posiadał również swój własny majątek osobisty, z którego mógłby korzystać na wyłączność. Tym samym, w ustroju wspólności każdy z małżonków jest dysponentem dwóch mas majątkowych, tj. majątku wspólnego oraz majątku osobistego. Stworzenie takiej odrębnej masy majątkowej, oznaczać może, iż prawodawca chroni interes indywidualny matżonka oraz honoruje jego autonomicznośćc ${ }^{40}$.

Z tego punktu widzenia (zważywszy na tę autonomiczność i interes prawny małżonka osoby zajmującej kierownicze stanowisko państwowe, z którą pozostaje on w rozdzielności majątkowej) można podnosić wątpliwość, czy ingerencja ustawodawcy w prywatność tych osób nie byłaby w tym wypadku zbyt daleko idąca z punktu widzenia ochrony prywatności, jak również zasady proporcjonalności wynikającej z art. 31 ust. 3 Konstytucji $\mathrm{RP}^{41}$.

W myśl ugruntowanej linii orzeczniczej TK wartości konstytucyjne moga zostać ograniczone „dla realizacji innej normy konstytucyjnej, poddajacej pod ochronę dobro, które w danym przypadku posiada pierwszeństwo przed prywatnością. Ograniczenia sa dopuszczalne, jeżeli umożliwiaja ochronę bezpieczeństwa państwa, porzadku publicznego, zdrowia, moralności publicznej, środowiska albo wolności lub

dotychczasowy majątek osobisty istniejacy przed zawarciem intercyzy lub przed zawarciem małżeństwa, jak i nabyty po jej zawarciu oraz udziat w majątku wspólnym powstałym przed zawarciem intercyzy,

2) każdy z małżonków zarządza i rozporządza całym swoim majątkiem samodzielnie,

3) małżonkowie traca możliwość wspólnego opodatkowania dochodów podlegajacych podatkowi dochodowemu od osób fizycznych,

4) małżonkowie moga dokonać $w$ drodze umowy lub na drodze sądowej podziału majątku wspólnego istniejącego do czasu zawarcia umowy wyłączającej wspólność, A. Brzezińska, Intercyzy - umowy małżeńskie, 2007, LEX.

40 J.M. Łukasiewicz, Małżeńska współzależność majątkowa w polskim prawie cywilnym, 2018, Legalis. Autor ten stwierdza również, że: Występowanie trzech mas majątkowych nie oznacza, że nie istnieja pomiędzy nimi żadne powiązania. Należy pamiętać, że matżonkowie sa obowiązani do udzielania sobie wzajemnie pomocy (art. $23 \mathrm{KRO}$ [Kodeks rodzinny i opiekuńczy - dopisek I.G.-R.]), ciąży na nich obowiązek przyczyniania się do zaspokajania potrzeb rodziny (art. $27 \mathrm{KRO}$ ), a w przypadku gdy majątek osobisty jednego z małżonków obejmuje mieszkanie, wówczas drugi małżonek posiada uprawnienie do korzystania $z$ tego mieszkania (art. $28^{1}$ KRO). Niemniej ważna jest regulacja art. $29 \mathrm{KRO}$, która pozwala jednemu z matżonków na tymczasowy zarząd majątkiem osobistym drugiego matżonka, w przypadku wystąienia przemijającej przeszkody.

${ }^{41}$ Ograniczenia $w$ zakresie korzystania $z$ konstytucyjnych wolności i praw moga być ustanawiane tylko $w$ ustawie i tylko wtedy, gdy sa konieczne $w$ demokratycznym państwie dla jego bezpieczeństwa lub porzadku publicznego, bądź dla ochrony środowiska, zdrowia i moralności publicznej, albo wolności i praw innych osób. Ograniczenia te nie moga naruszać istoty wolności i praw. 
praw innych osób. Musza one być zgodne z zasada proporcjonalności. Ustanowione ograniczenia spetniaja ten ostatni wymóg, jeżeli wprowadzona regulacja ustawodawcza jest w stanie doprowadzić do zamierzonych przez nią skutków (zasada przydatności), regulacja ta jest niezbędna dla ochrony interesu publicznego, z którym jest powiązana (zasada konieczności), a ponadto - jej efekty pozostaja w proporcji do ciężarów nakładanych przez nia na obywatela (zasada proporcjonalności wścistym tego słowa znaczeniu)" [Tak TK w uzasadnieniu wyr. z 20.6.2005 r., K 4/04, OTK-A 2005, Nr 6, poz. 64.] Ingerencja w sferę prywatności jednostki może okazać się konieczna dla eliminowania zagrożeń dla istnienia demokratycznego państwa prawnego [Tak TK w uzasadnieniu wyr. z 13.2.2001 r., K 19/99, OTK 2001, Nr 2, poz. 30] ${ }^{42}$.

$\mathrm{Z}$ jednej strony można przyjmować, że proponowane rozszerzenie obowiązku składania oświadczenia majątkowego - w taki sposób, iż obejmowałoby ono obok majątku wspólnego i majątku osobistego osoby zobowiązanej do jego złożenia również majątek osobisty małżonka - mogłoby być uznane za niezgodne z konstytucyjną zasadą proporcjonalności. Ustawa ograniczałaby bowiem prawa osób niepełniących żadnych funkcji publicznych jedynie z tego powodu, że ich małżonkowie sprawują takie funkcje.

$Z$ drugiej zaś strony, jeżeli przypisywać intencjom projektodawców wzgląd na wartości konstytucyjne, takie jak np. dążenie do zapewnienia obywatelom dostępu do informacji publicznej oraz dbałość o porządek publiczny czy moralność publiczną, to proponowane ograniczenie prywatności osób, do których odnosi się projekt, oraz ich małżonków można by oceniać jako regulację znajdującą konstytucyjne uzasadnienie (z punktu widzenia art. 31 ust. 3 Konstytucji).

3. Odnosząc się do możliwości nałożenia obowiązku wykazywania w oświadczeniu majątkowym składników mienia stanowiących majątek odrębny (osobisty) małżonka osoby zajmującej kierownicze stanowisko państwowe, należy określić istotę małżeńskich umów majątkowych (a przede wszystkim intercyzy). Wśród cech takich umów wymienia się ich organizacyjny charakter. Przez pojęcie umowy o charakterze organizacyjnym należy rozumieć to: że głównym jej celem jest regulowanie - organizowanie - relacji majątkowych pomiędzy małżonkami na przyszłość. Czy też inaczej - umowa taka służyć ma wyłacznie wprowadzeniu ustroju umownego. Jest to więc swoistego rodzaju "regulamin” małżonków określajacy zasady, wedle których małżonkowie w sferze majątkowej będa się obracać. Matżeńska umowa majątkowa nigdy zaś nie prowadzi do zmiany reżimu prawnego konkretnego prawa lub przedmiotu. Nie prowadzi do przesunięć składników majątkowych z jednej masy majątkowej do drugiej. Nie rozstrzyga o teraźniejszym majątku, lecz organizuje przynależność takich przedmiotów na przyszłośćt3.

42 R. Piotrowski, Prawo do prywatności, op. cit.

43 Tak: J.M. Łukasiewicz [w:] S. Grobel, R. Łukasiewicz, J. Wiktor, Instytucje prawa rodzinnego, 2014, LEX, i wskazana tam literatura. W doktrynie występują jednak znaczne rozbieżności między intercyzą ujmowaną jako umowa ściśle organizacyjna a inter- 
Niezależnie od ustroju majątkowego (czyli wspólności majątkowej, czy rozdzielczości dokonanej umownie w ramach intercyzy) istnieje zbiór uprawnień i obowiązków o charakterze majątkowym, który dotyczy wszystkich małżonków. W doktrynie wskazuje się przepisy regulujące skutki majątkowe zawarcia małżeństwa mające charakter bezwzględnie obowiązujący, niezależnie od ustroju majątkowego między małżonkami w sposób następujący: Charakter iuris cogentis maja także przepisy dotyczace pewnych praw najistotniejszych dla funkcjonowania rodziny, w tym przede wszystkim praw do mieszkania oraz przedmiotów wyposażenia domowego. Wynika to stą, że małżonkowie maja obowiązek wspólnego pożycia oraz przyczyniania się do zaspokojenia potrzeb rodziny, która założyli (por. art. $680^{1} \mathrm{KC}, 28^{1} \mathrm{KRO}$ ). Tak więc zmiana ustroju majątkowego $w$ formie zawartej przez małżonków umowy nie powinna nic zmieniać w zakresie praw i obowiązków małżonków, wynikających z przepisów art. 23, 27 i 281 KRO. Zmiana ustroju majątkowego - ze wspólności ustawowej na rozdzielność majątkowa - nie może być przyjmowana jako zerwanie więzi gospodarczej (więź gospodarcza w prawidłowo funkcjonującym małżeństwie jest zachowana niezależnie od ustroju majątkowego, w jakim funkcjonuja małżonkowie).

Reasumując, niezależnie od tego, czy małżonkowie pozostają we wspólnocie majątkowej, czy też ustanowili rozdzielność, mają do nich zastosowanie przepisy art. 23-30 Kodeksu rodzinnego i opiekuńczego regulujące zarówno niemajątkowe, jak i majątkowe prawa i obowiązki małżonków, które tworzą tzw. ustrój podstawowy ${ }^{44}$. Przyjęcie przez małżonków ustroju rozdzielności majątkowej nie zwalnia ich od wypełniania wszystkich obowiązków, jakie wynikają z zasad prawa rodzinnego. Jak wskazuje się w doktrynie: [...] jedna z cech charakteryzujacych związek małżeński, jako stosunek prawny, jest waski margines swobody woli podmiotów tego stosunku w kształtowaniu jego treści. Reguła jest, że zawarcie małżństwa wywołuje skutki wynikające z przepisów bezwzględnie obowiązujacych. Do nielicznych wyjątków, w których znajduje pewien wyraz wola matżonków, zaliczyć można swobodę ukształtowania matżeńskiego ustroju majątkowego. Jednak $i$ w tym przypadku ustawa zakreśla granice swobody woli małżonków ${ }^{45}$.

Treść małżeńskiej umowy majątkowej nie może być sprzeczna z naczelnymi zasadami prawa rodzinnego. W szczególności dotyczy to zasady równouprawnienia małżonków. Jako przykład w tej mierze podaje się, że nieważne byłyby postanowienia umowy wyłączające ze wspólności pobrane wynagrodzenie za

cyzą zawierającą elementy rozporządzenia konkretnymi prawami majątkowymi (na co zwraca uwagę T. Sokołowski, Swoboda intercyzy. Zakres modyfikacji małżeńskich ustrojów majątkowych, 2013, LEX).

44 Szerzej na ten temat G. Jędrejek, Umowy majątkowe małżonków (intercyzy), 2012, Legalis.

45 J. Gajda, T. Smyczyński [w:] System prawa prywatnego, t. 11, Prawo rodzinne i opiekuńcze, red. T. Smyczyński, 2014, Legalis. 
pracę lub inne usługi, świadczone tylko przez jednego z małżonków, przy objęciu wspólnością wynagrodzenia przysługującego drugiemu z nich ${ }^{46}$.

Małżonkowie, którzy zawrą umowę majątkową, są zobligowani do przestrzegania obowiązków wynikających z założenia rodziny, w tym obowiązku przyczyniania się do zaspokajania potrzeb rodziny $\mathrm{w}$ miarę swych sił i możliwości zarobkowych, wychowania dzieci i pracy we wspólnym gospodarstwie domowym, obowiązku wzajemnej pomocy i współdziałania dla dobra rodziny, wspólnego rozstrzygania o jej istotnych sprawach itp. ${ }^{47}$.

Istotna z punktu widzenia omawianej kwestii wydaje się również teza wyroku Sądu Apelacyjnego w Szczecinie z 12 lutego 2014 r. (sygn. akt I Aca 785/13): Zmiana $w$ trakcie małżeństwa ustroju majątkowego $w$ formie zawartej przez matżonków umowy w zasadzie nie powinna niczego zmieniać $w$ zakresie praw i obowiązków matżonków, wynikających $z$ art. 23, 27 i $28^{1}$ k.r.o. Zmiana ustroju majątkowego - ze wspólności ustawowej na rozdzielność majątkowa - nie może być przyjmowana jako zerwanie więzi gospodarczej.

Przytoczone powyżej poglądy doktryny co do szczególnej prawnorodzinnej funkcji umów majątkowych (ustalających rozdzielność majątkową małżonków) pozwalają na przyjęcie poglądu, że charakter takich umów nie powinien stanowić przeszkody w nałożeniu zobowiązania wykazywania w oświadczeniu o stanie majątkowym majątku osobistego małżonka osoby pełniącej kierownicze stanowisko państwowe.

4. Należy przypuszczać, że celem proponowanej ustawy jest m.in. zapobieganie zjawisku „ukrywania” majątku wspólnego małżonków przez osoby pełniące funkcje publiczne w drodze dokonywania czynności rozporządzających składnikami majątkowymi w czasie pełnienia tych funkcji ${ }^{48}$, w tym również przeciwdziałanie sytuacji, w której następuje przysporzenie majątkowe na rzecz osoby pełniącej funkcję publiczną, ale do majątku osobistego jej małżonka.

46 Ibidem.

${ }^{47}$ W opinii A. Brzezińskiej: W ustroju rozdzielności majątkowej wszelkie relacje i powiązania majątkowe, czy to $w$ odniesieniu do nakładów czy umów zawieranych między małżnkami, podlegaja przepisom kodeksu cywilnego. Tak więc przedmiot nabyty wspólnie przez małżonków w czasie trwania ustroju rozdzielności majątkowej będzie stanowić przedmiot współwłasności w częściach ułamkowych. Do zarządu majątkiem objętym współwłasnościa moga być stosowane wyłącznie przepisy kodeksu cywilnego (art. 195-221 k.c.) o współwłasności, eadem, Intercyzy - umowy małżeńskie, op. cit.

48 Sąd Najwyższy w uchwale składu siedmiu sędziów z 10 kwietnia 1991 r., sygn. akt III CZP 76/90, odpowiadając na pytanie: „czy w czasie trwania wspólności ustawowej dopuszczalne jest rozporządzanie przez małżonków poszczególnymi składnikami majątku wspólnego na rzecz majątków odrębnych każdego z małżonków?” stwierdził, że: W czasie trwania ustawowej wspólności majątkowej dopuszczalne jest rozporządzenie przez małżonka przedmiotem wchodzacym w skład majątku wspólnego na rzecz majątku odrębnego drugiego małżonka. 
W komentarzu do art. 61 Konstytucji RP stwierdzono m.in.: Informacje o majątku i sytuacji ekonomicznej jednostki sa objęte gwarancjami autonomii informacyjnej, jakkolwiek $w$ tej sferze występuja łagodniejsze przesłanki dopuszczalnej ingerencji niż w wypadku sfery czysto osobistej (wyr. TK z 20.6.2005 r., K 4/04, OTK-A 2005, Nr 6, poz. 64; 24.6.1997 r., K 21/96, OTK 1997, Nr 2, poz. 23; 11.4.2000 r., K 15/98, OTK 2000, Nr 3, poz. 86). Ma to szczególne znaczenie w odniesieniu do przepisów przewidujących obowiązki informacyjne w związku z zapobieganiem zjawiskom korupcyjnym. Ograniczenia w tym zakresie sa dopuszczalne w szczególności $w$ odniesieniu do osób petniących funkcje publiczne oraz członków ich rodzin. Taka funkcje petni m.in. obowiązek złożenia przez osoby piastujące funkcje publiczne oświadczenia o swoim stanie majątkowym. Jako całkowicie akceptowalny uznaje się także m.in. obowiązek podawania informacji o zasobach pieniężnych, nieruchomościach, udziałach $i$ akcjach w spółkach prawa handlowego oraz o nabyciu od Skarbu Państwa, innej państwowej osoby prawnej, gminy lub związku międzygminnego, mienia, które podlegało zbyciu w drodze przetargu, dane o prowadzeniu działalności gospodarczej oraz dotyczace zajmowania stanowisk $w$ spółkach prawa handlowego. Nie budzi również zastrzeżeń konstytucyjny obowiazek udzielania przez funkcjonariuszy publicznych informacji dotyczacych majątku objętego wspólnościa majątkowa małżeńską, majątku odrębnego osoby składającej oświadczenie, obowiązek składania oświadczeń o działalności gospodarczej prowadzonej przez funkcjonariusza publicznego, jak również jego matżonka, wstępnych, zstępnych i rodzeństwo (zob. zwłaszcza wyr. TK z: 13.7.2004 r., K 20/03, OTK-A 2004, Nr 7, poz. 63; 6.12.2005 r., SK 7/05, OTK-A 2005, Nr 11, poz. 129; 23.2.2010 r., K 1/08, OTK-A 2010, Nr 2, poz. 14$)^{49}$.

Można dodać, że do sfery prywatnej i autonomii informacyjnej jednostki zaliczają się również informacje dotyczące majątku, tj. informacje o sferze ekonomicznej jednostki. Kryteria wkraczania w tę sferę są łagodniejsze niż w wypadku sfery osobistej (zob. wyrok TK w sprawie o sygn. akt K 41/02 i teza powtórzona m.in. w wyroku w sprawie o sygn. akt TK SK 7/05).

5. Nawet gdyby w omawianym zakresie przyznawać majątkowi osobistemu (w tym umowom małżeńskim) szczególną rolę, jaką nadaje im prawo cywilne, wydaje się, że możliwe jest wprowadzenie omawianego rozwiązania ze względu na ważny interes publiczny, jakim jest wprowadzenie skuteczniejszych rozwiązań mających na celu przeciwdziałanie praktykom korupcyjnym.

W literaturze podkreśla się, że korupcja jest identyfikowana m.in. jako: zachowanie władz publicznych, polityków i urzędników, w wyniku którego wzbogacaja się oni $w$ sposób bezprawny i nieuzasadniony lub przyczyniaja się do wzbogacenia osób sobie bliskich, poprzez niewłaściwe wykorzystanie powierzonej im władzy oraz sprzeniewierzane się zasadzie oddzielenia życia prywatnego od życia zawodo-

49 M. Wild [w:] Konstytucja RP, t. I, Komentarz. Art. 1-86, red. M. Safjan, L. Bosek, Warszawa 2016. 
wego ${ }^{50}$. W tym wypadku można by przypisywać proponowanemu rozwiązaniu rolę, jaką ma spełniać kontrola oświadczeń o stanie majątkowym.

$\mathrm{Na}$ antykorupcyjny charakter oświadczeń o stanie majątkowym zwraca uwagę m.in. A. Wierzbica ${ }^{51}$, powołując przy tym stanowisko S. Koroluka, który uznaje, że gwarancją bezstronności (zapobiegania konfliktowi między interesem publicznym i prywatnym) jest narzędzie w postaci kontroli stanu majątkowego dokonywanej przez składanie tzw. oświadczeń o stanie majątkowym ${ }^{52}$. Informacja odnosząca się np. do majątku osobistego małżonka przed rozpoczęciem sprawowania funkcji przez osobę składającą oświadczenie, w trakcie sprawowania tej funkcji oraz po jej zakończeniu, mogłaby przyczyniać się do takiej kontroli.

W związku z powyższym proponowane $\mathrm{w}$ projekcie rozwiązanie można oceniać jako ograniczenie prywatności (wynikającej z art. 47 Konstytucji), ale ustanowione w ramach realizacji innej normy konstytucyjnej służącej dobru, jakim jest porządek publiczny i moralność publiczna, o których mowa w art. 31 ust. 3 Konstytucji ${ }^{53}$. W związku z tym zobowiązanie osób zajmujących kierownicze stanowiska państwowe (wskazane w art. 1 projektu) do wykazywania w oświadczeniu o stanie majątkowym majątku osobistego małżonka, w ocenie autorki opinii, jest dopuszczalne.

\section{Upublicznianie danych adresowych, informacji o położeniu nieruchomości oraz informacji umożliwiających identyfikację ruchomości wykazywanych w oświadczeniach o stanie majątkowym (w tym w zakresie majątku osobistego małżonka osoby składającej oświadczenie)}

1. Z brzmienia proponowanej regulacji wynika, że informacje zawarte w oświadczeniu o stanie majątkowym byłyby ex lege jawne i nie korzystałyby $\mathrm{z}$ ochrony

50 M. Jabłoński, Obowiązek wdrożenia procedur antykorupcyjnych - uwagi na tle propozycji zawartych w projekcie ustawy o jawności życia publicznego, „Przegląd Prawa i Administracji, Acta UWr" 2018, t. CXIV.

51 Eadem, Analiza obowiązujących przepisów antykorupcyjnych $z$ wykazaniem mankamentów prawnych [w:] Korupcja i antykorupcja. Wybrane zagadnienia, cz. I, red. J. Kosiński, A. Koman, Warszawa 2011.

52 S. Koroluk, Glosa do wyroku SN I PK 107/02, „Gdańskie Studia Prawnicze - Przegląd Orzecznictwa" 2005, nr 3, poz. 17.

53 Według M. Laskowskiej: Ochrona prywatności może zostać ograniczona dla realizacji innej normy konstytucyjnej służącej dobru, które $w$ danym przypadku ma przed nia pierwszeństwo. Ograniczenia sa więc dopuszczalne, jeżeli umożliwiają ochronę bezpieczeństwa państwa, porzadku publicznego, zdrowia, moralności publicznej, środowiska albo wolności lub praw innych osób, eadem, Prawo do informacji o działalności osób petniących funkcje publiczne a ich prawo do ochrony prawnej życia prywatnego. Refleksje na tle orzecznictwa TK [w:] Obywatelskie prawo do informacji, red. T. Gardocka, Warszawa 2008. 
przewidzianej dla informacji niejawnych. Oświadczenie o stanie majątkowym osób określonych w art. 1 projektu stanowiłoby w całości informację publiczną udostępnianą w BIP ${ }^{54}$. Oznacza to, że ujawnieniu i publicznemu udostępnieniu podlegałby szeroki zakres danych, takich jak dane adresowe, informacje o położeniu nieruchomości czy informacje umożliwiające identyfikację ruchomości osoby składającej oświadczenie i jej małżonka ${ }^{55}$. Co istotne, w projekcie nie przewidziano możliwości odstąpienia od zasady jawności, jeżeli ujawnienie takich informacji mogłoby powodować zagrożenie dla składającego oświadczenie lub osób dla niego najbliższych ${ }^{56}$.

To poważne ograniczenie podmiotowego prawa prywatności powinno podlegać bardziej rygorystycznej ocenie zgodności z art. 51 Konstytucji niż samo wprowadzenie obowiązku złożenia takiego oświadczenia, zwłaszcza że będzie odnosić się również do małżonków (czyli osób niepełniących funkcji publicznych).

Trybunał Konstytucyjny podkreślał, że w ramach zderzenia się dwóch wartości - z jednej strony konstytucyjnego prawa do informacji, $\mathrm{z}$ drugiej prawa do prywatności - nie można bezwzględnie przyznać priorytetu temu pierwszemu. Nie istnieje formuła: zagwarantowania obywatelom dostępu do informacji „za wszelka cenę" (wyrok z 19 czerwca 2002 r. w sprawie o sygn. akt K 11/02). Jednocześnie TK uznał (sygn. akt K 17/05), że prywatność i autonomia informacyjna (która oznacza prawo do samodzielnego decydowania o ujawnianiu innym informacji dotyczących swojej osoby) obejmują informacje o majątku i sferze ekonomicznej jednostki (zob. wyrok w sprawie o sygn. akt K 41/02 i przytoczone tam orzecznictwo).

Sąd konstytucyjny zwracał również uwagę na aspekt tzw. usprawiedliwionego zainteresowania publicznego (sygn. akt K 24/98) oraz konieczność zachowania mechanizmu proporcjonalności z art. 31 ust. 3 Konstytucji. Aspekt ten nie zo-

54 Co wynika a contrario z art. 10 ust. 3-3b ustawy antykorupcyjnej stanowiącego, że z zastrzeżeniem zachowania określonych ustawowo warunków jawne są tylko niektóre kategorie informacji zawarte w oświadczeniu o stanie majątkowym złożonym przez Prezesa Naczelnego Sądu Administracyjnego, Pierwszego Prezesa Sądu Najwyższego, Prezesa Narodowego Banku Polskiego, wiceprezesów NBP oraz osób, o których mowa w art. 2 pkt $6 \mathrm{~d}$ ustawy antykorupcyjnej.

55 Zob. art. 10 ust. 3a ustawy antykorupcyjnej ustanawiający wyjątek od zasady jawności informacji zawartych w oświadczeniu o stanie majątkowym złożonym przez wymienione $\mathrm{w}$ tym przepisie osoby.

56 Zob. z art. 10 ust. 3a ustawy antykorupcyjnej stanowiącym, że: [...] na wniosek osoby składającej oświadczenie osoba odbierająca oświadczenie może zdecydować o objęciu informacji zawartych $w$ oświadczeniu ochrona przewidziana dla informacji niejawnych o klauzuli tajności „zastrzeżone”, określona w przepisach ustawy z dnia 5 sierpnia 2010 r. o ochronie informacji niejawnych (Dz.U. z 2019 r. poz. 742), jeżeli ujawnienie tych informacji mogłoby powodować zagrożenie dla składającego oświadczenie lub osób dla niego najbliższych. Minister Sprawiedliwości jest uprawniony do zniesienia tej klauzuli. 
stał poddany w uzasadnieniu projektu analizie, co przy tak poważnym ograniczeniu prawa do prywatności zarówno osób pełniących kierownicze stanowiska państwowe, jak również ich małżonków, pozwala na negatywną ocenę projektu w zakresie jego zgodności z art. 61 ust. 1 i art. 31 Konstytucji. Według Trybunału: [...] prywatność może w pewnych sytuacjach być przedmiotem ingerencji dla ochrony dobra wspólnego, jednak wkraczanie w te sferę, również tam, gdzie w wyraźny sposób styka się ona ze sferę publiczna, musi być dokonywane w sposób ostrożny i wyważony, z należyta ocena racji, które przemawiaja za taka ingerencja. Mamy, bowiem do czynienia $z$ dobrami równorzędnymi ${ }^{57}$.

Projektodawcy nie przedstawili tych racji, a dla wprowadzenia tak znacznego stopnia jawności oświadczeń nie wystarczy stwierdzenie zawarte w uzasadnieniu, że: $w$ ostatnim czasie $w$ przestrzeni medialnej pojawiło się wiele informacji o majątkach odrębnych matżonków osób petniących funkcje publiczne.

2. W omawianym przypadku ingerencja ustawodawcy w prywatność osób pełniących funkcje publiczne (wskazanych w proponowanym art. 1 ust. 1a ustawy), a zwłaszcza ich małżonków (jako osób niepełniących funkcji publicznych, które podlegają szerszej ochronie) mogłaby zostać uznana za naruszającą zasadę proporcjonalności (art. 31 ust. 3 Konstytucji), która nakazuje ważenie konstytucyjnie chronionego prawa do prywatności każdego obywatela (w tym jego stanu majątkowego) i ochrony danych osobowych (art. 47 i 51 Konstytucji) oraz prawa do informacji o osobach pełniących funkcje publiczne (art. 61).

Proponowanymi przepisami ustawodawca zdaniem autorki niniejszej opinii przekroczyłby granice dopuszczalnej ingerencji w sferę prywatną nie tylko osób pełniących funkcje publiczne, ale również osób niepełniących takiej funkcji. Konstruując przepisy ingerujące głęboko w sferę prywatności jednostki, ustawodawca musi rozważyć proporcjonalność zastosowanego środka do celu, jaki chce osiągnąć, i nie wystarczy przy tym, aby zastosowane środki sprzyjały zamierzonym celom (tak TK w wyroku K 17/05). Chodzi bowiem o zastosowanie środków niezbędnych (koniecznych) w tym sensie, że będą one chronić określone wartości w sposób lub stopniu, który nie mógłby być osiągnięty przy zastosowaniu innych środków, a jednocześnie winny to być środki jak najmniej uciążliwe dla podmiotów, których prawo bądź wolność ulegają ograniczeniu (w ten sposób TK w wyroku K 32/04).

Publikowanie danych adresowych i innych, o których mowa, nie sposób uznać za środek najmniej uciążliwy dla adresatów proponowanych rozwiązań, a zatem rozwiązania te nie mogą być ocenione jako zgodne z zasadą proporcjonalności wynikającą $z$ art. 31 ust. 1 Konstytucji.

Zdaniem Trybunału Konstytucyjnego art. 31 ust. 3 zdanie pierwsze statuuje zasadę proporcjonalności, określaną też jako zakaz nadmiernej ingerencji. Trybunał za aktualne uznał stwierdzenie (zawarte w orzeczeniu z 26 kwietnia 1995 r.,

57 Wyrok TK z 20 marca 2006 r. w sprawie o sygn. akt K 17/05. 
sygn. akt K. 11/94, i wielokrotnie powtarzane w dalszym orzecznictwie), że dla oceny, czy doszło do naruszenia zasady proporcjonalności (zakazu nadmiernej ingerencji) konieczne jest udzielenie odpowiedzi na trzy pytania: 1) czy wprowadzona regulacja ustawodawcza jest $w$ stanie doprowadzić do zamierzonych przez nią skutków; 2) czy regulacja ta jest niezbędna dla ochrony interesu publicznego, $z$ którym jest powiązana; 3) czy efekty wprowadzanej regulacji pozostaja w proporcji do ciężarów nakładanych przez nią na obywatela. Zwrócił też uwagę, że art. 31 ust. 3 zdanie pierwsze Konstytucji szczególny nacisk położył na kryterium „konieczności w demokratycznym państwie”. Oznacza to, że każde ograniczenie praw i wolności jednostki musi być w pierwszym rzędzie oceniane w płaszczyźnie pytania, czy było ono konieczne, czyli - innymi słowy, czy tego samego celu (efektu) nie można było osiągnąć przy użyciu innych środków, mniej uciążliwych dla obywatela, bo słabiej (bardziej płytko) ingerujących w sferę jego praw i wolności. Powyższa formuła zasady proporcjonalności została również potwierdzona w wyroku z 3 października 2000 r., sygn. akt K 33/99.

W świetle utrwalonego orzecznictwa Trybunału Konstytucyjnego ingerencja ustawodawcy w sferę praw i wolności osób pełniących funkcje publiczne powinna odbywać się z poszanowaniem reguł ochrony prywatności (w tym zwłaszcza w odniesieniu do małżonków tych osób). W związku z tym należy uznać, że przyjęcie rozwiązań proponowanych w projekcie w omawianym zakresie może prowadzić do naruszenia zasad wynikających z art. 47, art. 51 oraz art. 31 ust. 3 Konstytucji.

\section{Podsumowanie}

- Określenie zakresu podmiotowego proponowanej ustawy w art. 1 projektu może budzić wątpliwości z punktu widzenia zasady równości (art. 32 ust. 1 Konstytucji RP) stosowanej w odniesieniu do osób pełniących kierownicze stanowiska państwowe jako podgrupy w katalogu osób pełniących funkcje publiczne w zakresie ujawniania posiadanego majątku, jak również upubliczniania składanych przez te osoby oświadczeń o stanie majątkowym.

- Oświadczenia majątkowe wskazanych w projekcie osób byłyby jawne i podlegałyby publikacji w Biuletynie Informacji Publicznej. Ustalenie zasady jawności oświadczeń kolejnej grupy osób pełniących najważniejsze funkcje publiczne, jak również publikowanie (upublicznianie) tych oświadczeń w BIP nie budzi zastrzeżeń konstytucyjnych. Poważne zastrzeżenie budzi jednakże wynikająca z projektu zasada upubliczniania danych adresowych, informacji o położeniu nieruchomości oraz informacji umożliwiających identyfikację ruchomości osoby składającej oświadczenie. Rozwiązanie takie może stanowić naruszenie zasad ustalonych w art. 47 Konstytucji (prawa do prywatności) oraz art. 31 ust. 3 Konstytucji (zasady proporcjonalności). 
- Wprowadzenie obowiązku wykazywania w oświadczeniu majątkowym majątku osobistego małżonka osoby składającej oświadczanie wydaje się dopuszczalne w świetle dotychczasowego orzecznictwa Trybunału Konstytucyjnego oraz charakteru małżeńskich umów majątkowych, jednakże poważne wątpliwości konstytucyjne budzi publikowanie takich oświadczeń w BIP wraz z danymi adresowymi, informacją o położeniu nieruchomości itp.

\section{Bibliografia}

Bobiec A., Informacja publiczna a ochrona prywatności osób petniących funkcje publiczne [w:] Jawność w samorządzie terytorialnym, red. B. Dolnicki, Warszawa 2015.

Brzezińska A., Intercyzy - umowy matżeńskie, 2007, LEX.

Dral A., Sytuacja prawna osób zatrudnionych na kierowniczych stanowiskach państwowych - uwagi de lege lata i de lege ferenda, „Administracja: Teoria, Dydaktyka, Praktyka” 2009, nr 1(14).

Gajda J., Smyczyński T. [w:] System prawa prywatnego, t. 11, Prawo rodzinne i opiekuńcze, red. T. Smyczyński, 2014, Legalis.

Jabłoński M., Obowiązek wdrożenia procedur antykorupcyjnych - uwagi na tle propozycji zawartych w projekcie ustawy o jawności życia publicznego, „Przegląd Prawa i Administracji, Acta UWr" 2018, t. CXIV.

Jabłoński M., Wygoda K., Ustawa o dostępie do informacji publicznej. Komentarz, Wroclaw 2002.

Janaczek K., Oświadczenia majątkowe pracowników samorządowych i radnych - zarys problemu w kontekście jawności działania samorzadu terytorialnego [w:] Jawność w samorzadzie terytorialnym, red. B. Dolnicki, Warszawa 2015.

Jędrejek G., Umowy majątkowe małżonków (intercyzy), 2012, Legalis.

Juchniewicz J., Status radnego gminy [w:] Status prawny rady gminy, red. M. Chmaj, Warszawa 2012.

Karczewski J., Stawecki T., Prywatność i jawność - ważenie zasad prawnych [w:] Prywatność a jawność. Bilans 25-lecia i perspektywy na przyszłość, red. A. Mednis, Warszawa 2016.

Koroluk S., Glosa do wyroku SN I PK 107/02, „Gdańskie Studia Prawnicze - Przegląd Orzecznictwa" 2005, nr 3.

Kosiński J., Analiza obowiązujących przepisów antykorupcyjnych $z$ wykazaniem mankamentów prawnych [w:] Korupcja i antykorupcja. Wybrane zagadnienia, cz. I, red. J. Kosiński, A. Koman, Warszawa 2011.

Laskowska M., Prawo do informacji o działalności osób petniących funkcje publiczne a ich prawo do ochrony prawnej życia prywatnego. Refleksje na tle orzecznictwa TK [w:] Obywatelskie prawo do informacji, red. T. Gardocka, Warszawa 2008.

Łukasiewicz J.M. [w:] Grobel S., Łukasiewicz R., Wiktor J., Instytucje prawa rodzinnego, 2014, LEX. 
Łukasiewicz J.M., Małżeńska współzależność majątkowa w polskim prawie cywilnym, 2018, Legalis.

Piotrowski R., Prawo do prywatności i ochrony danych osobowych jako wartości konstytucyjne [w:] Prywatność a jawność. Bilans 25-lecia i perspektywy na przyszłość, red. A. Mednis, Warszawa 2016.

Rzetecka-Gil A., Ustawa o ograniczeniu prowadzenia działalności gospodarczej przez osoby pelniące funkcje publiczne. Komentarz, 2009, LEX.

Sibiga G., Dostęp do informacji publicznej a prawa do prywatności jednostki i ochrony jej danych osobowych, „Samorząd Terytorialny” 2003, nr 11.

Sokołowski T., Swoboda intercyzy. Zakres modyfikacji małżeńskich ustrojów majątkowych, 2013, LEX.

Stelina J., Stosunki pracy osób petniących funkcje organów państwa, Warszawa 2016.

Uliasz J., Prawo do prywatności osób petniących funkcje publiczne, „Samorząd Terytorialny" 2013, nr 3.

Wild M. [w:] Konstytucja RP, t. I, Komentarz. Art. 1-86, red. M. Safjan, L. Bosek, Warszawa 2016. 